\title{
SPINAL EXTRADURAL ARACHNOID CYSTS
}

\author{
CISTOS ARACNÓIDEOS EXTRADURAIS DA COLUNA \\ QUISTES ARACNOIDEOS EXTRADURALES DE LA COLUMNA
}

Abolfazl Rahimizadeh ${ }^{1}$, Mahmud Kaghazchi ${ }^{1}$, Majid Shariati ${ }^{1}$, Eidi Abdolkhani ${ }^{1}$,Enayatolah Abbasnejad ${ }^{1}$, Shaghayegh Rahimizadeh ${ }^{1}$

\begin{abstract}
Objective: Extradural arachnoid cysts (EACs) are rare causes of spinal cord compression and cauda equina. These benign lesions appear in the literature mainly as single case reports. In this article, we present the largest series found in literature, with four new cases of spinal extradural arachnoid cysts. The characteristic imaging features, details of surgical steps and strategies to prevent postoperative kyphosis in this cystic pathology will be discussed.
\end{abstract}

Keywords: Arachnoid cysts; Magnetic resonance imaging; Laminectomy; Kyphosis; Spinal cord.

\section{RESUMO}

Objetivo: Os cistos aracnóideos extradurais (EAC) são causa rara de compressão da medula espinal e de cauda equina. Essas lesões benignas aparecem na literatura principalmente como relatos de casos isolados. Neste artigo, é apresentada a maior série encontrada na literatura, com quatro novos casos de cistos aracnóideos extradurais da coluna. Discussão: São discutidas as características das imagens, os detalhes dos passos cirúrgicos e as estratégias para prevenir a cifose pós-operatória nessa patologia cística.

Descritores: Cistos aracnóideos; Imagem por ressonância magnética; Laminectomia; Cifose; Medula espinal.

\section{RESUMEN}

Objetivo: Los quistes aracnoideos extradurales (EAC) son causa rara de compresión de la médula espinal y de cauda equina. Estas lesiones benignas aparecen en la literatura principalmente como relatos de casos aislados. En este artículo, es presentada la mayor serie encontrada en la literatura, con cuatro nuevos casos de quistes aracnoideos extradurales de la columna. Son discutidas las características de las imágenes, los detalles de los pasos quirúrgicos y las estrategias para prevenir la cifosis postoperatoria en esa patología quística.

Descriptores: Quistes aracnoideos; Imagen por resonancia magnética; Laminectomía; Cifosis; Médula espinal.

\section{INTRODUCTION}

Spinal extradural arachnoid cysts are an uncommon entity and symptomatic cysts are rare. In the literature these cysts mostly appear as a single case reports or small series of two or three cases which indicate the rarity of these cysts. ${ }^{1-19}$ Spinal arachnoid cysts located extradurally are most often encountered at mid-thoracic or thoracolumbar region. Although, they are also known to occur in the lumbosacral, cervicothoracic and cervical spine in decreasing frequency. ${ }^{20}$ Majority of these cysts develop in the posterior aspect of the spinal column and an anterolaterally located cyst is an exception.

These lesions are mostly observed as a single cyst and multiple ones are less common. ${ }^{15,16,21-23}$ Spinal extradural arachnoid cysts may extend from a few levels up to several number of levels. ${ }^{7,11,20,24}$

Spinal EACs seems to be more frequent in male patients than female subjects and more common in children and adolescents rather than adults, with peak incidence in the second decade of life. ${ }^{1-19}$

In pre MRI era, reports on extradural arachnoid cysts were extremely rare. However, with widespread application of MRI, such cysts are diagnosed earlier and reported increasingly. ${ }^{12-20,22,25-29}$

Excision of the cyst with closure of the defect is the mainstay of treatment in symptomatic patients. 2,5,6,8,10,11,30

The current report illustrates the largest series in the literature including four symptomatic extradural arachnoid cysts in whom en-block excision of the cyst and obliteration of the dural de- fect result in excellent recovery. The crucial role of MRI and its characteristic features in accurate preoperative diagnosis will be emphasized. Moreover, alternative surgical techniques in management of these cysts and therapeutic options for overcoming a recurrence will be discussed. Furthermore, current strategies in the prevention and management of postoperative kyphosis in young children undergoing decompressive surgical interventions will be considered.

Case 1: A 23- year old woman was admitted because of severe low back pain radiating to her legs for two months duration. She had a history of mild low back pain in the last two years. Neurological examination revealed bilateral mild lower extremity weakness. MRI demonstrated well defined extradural cyst in the posterior aspect of the canal extending from T12 to L2 with marked compression of the conus from the left. The cyst had low intensity in T1 and hyperintensity in T2 images compatible with CSF. (Figure 1A). Spinal radiographs showed widening of the spinal canal with posterior scalloping of the vertebral bodies, thinning of the pedicles and increased interpedicular distance at T12and L1 levels (Figure 1B) After laminectomy from T12 to L2, a bluish cystic mass was seen which was meticulously separated from the surrounding tissues and removed totally. (Figure 1C) A small dural hole at L1 was identified and was subsequently closed with $5 / 0$ sutures (Figure 1D). After surgery the patient experienced complete relief of the symptoms. Pathological diagnosis was arachnoid cyst (Figure 1E). The patient has remained symptom free since then.

1. Department of Spinal Surgery, Pars Hospital, Tehran, Iran.

The work was performed at Department of Spinal Surgery, Pars Hospital, Tehran, Iran.

Mailling adress: Ray -Tehran 20th District, Tehran, Shahriyar. a_rahimizadeh@hotmail.com

Received 24/4/2013, accepted 29/5/2013. 


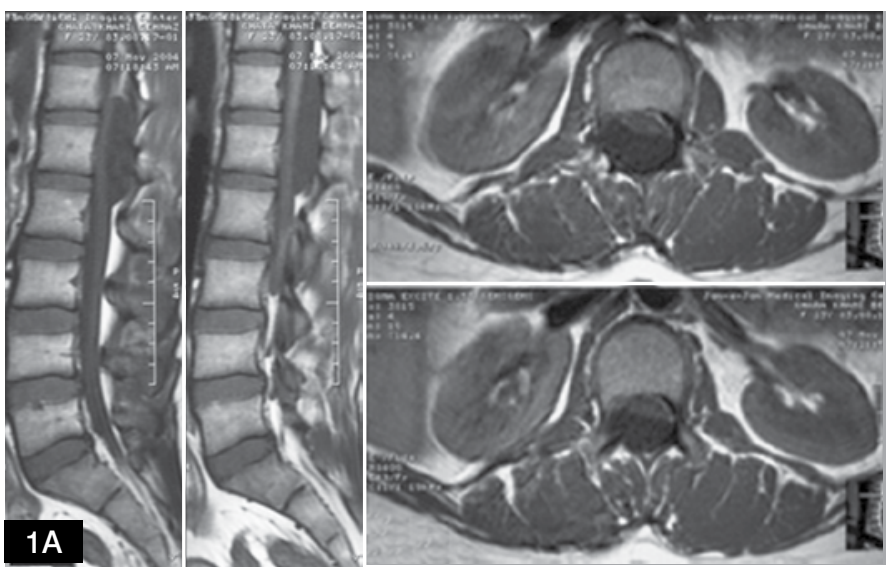

Figure 1A. T1 weighted image: Show a hypointense cystic mass at thoracolumbar regionwith signal intensity compatible with CSF.

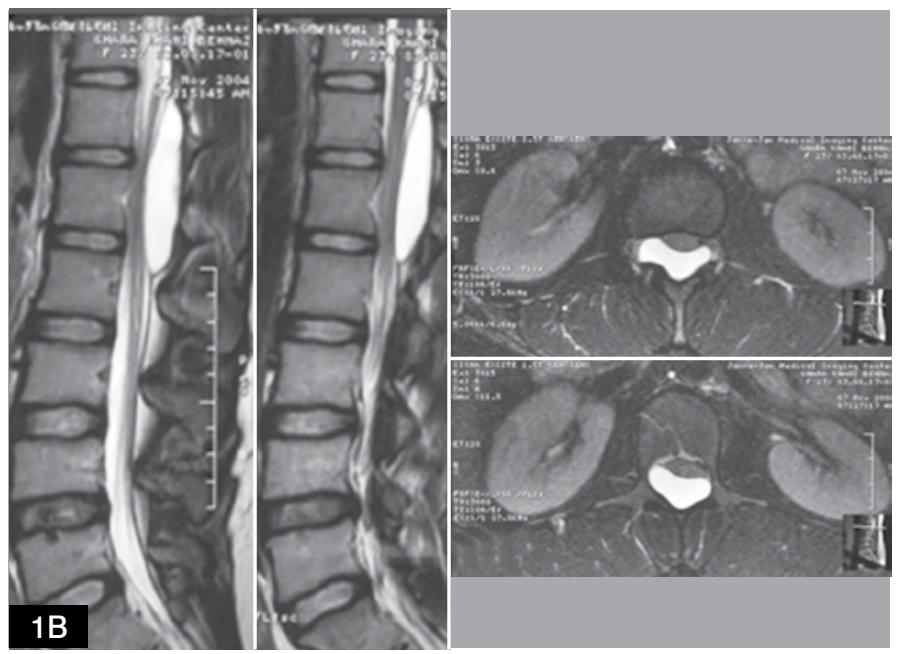

Figure 1B. T2 weighted sagittal and axial view demonstrating a hyperintense mass at posterior spinal canal at thoracolumbar region.

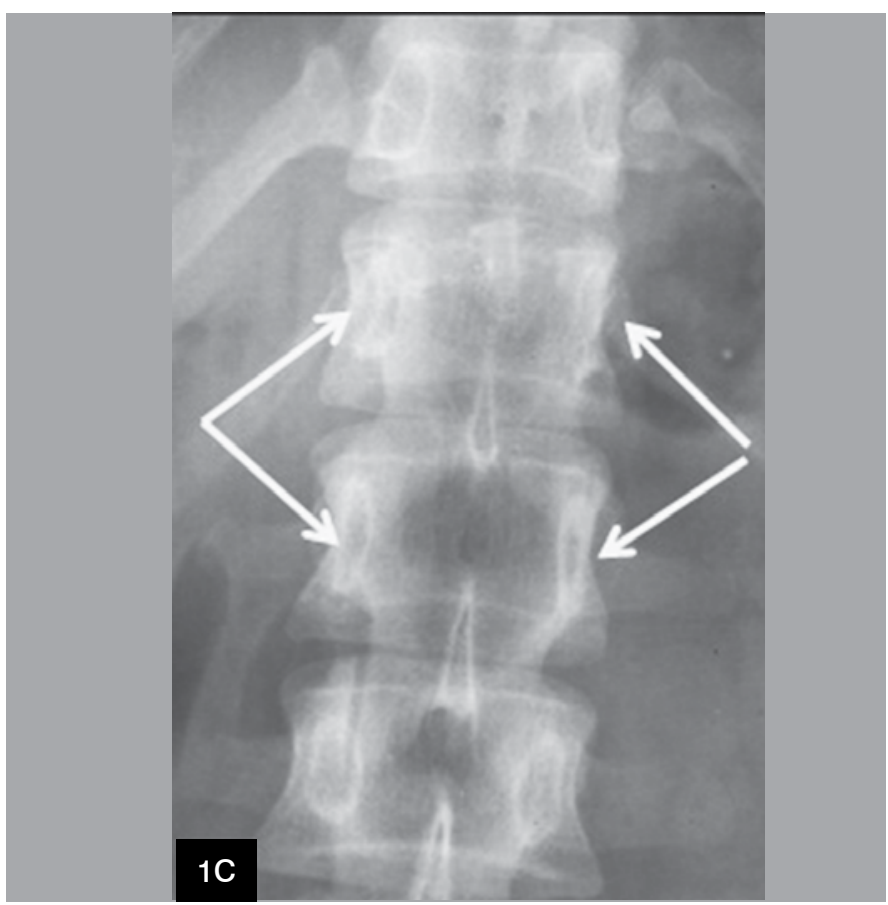

Figure 1C. AP plain X-Ray showing thinned pedicles.

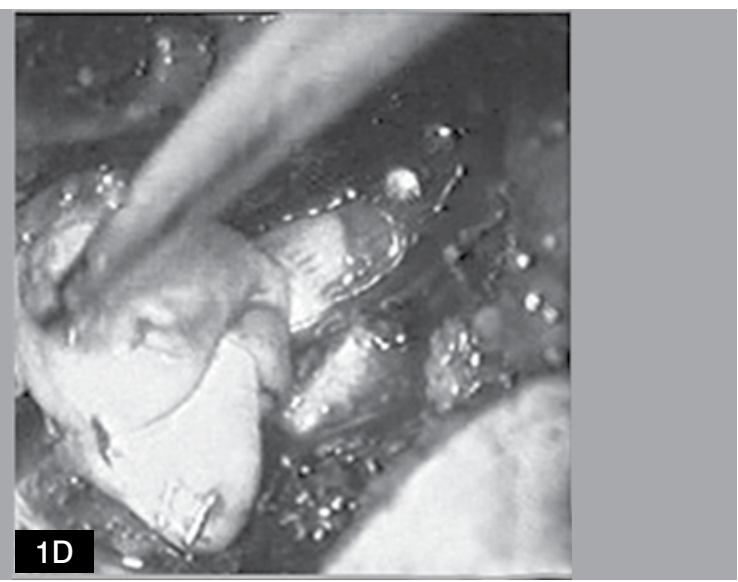

Figure 1D. A cyst is elevated from dura mater

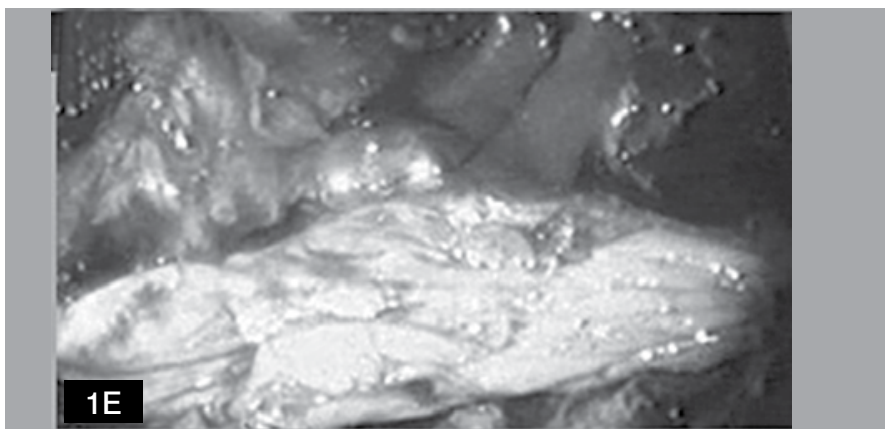

Figure 1E. Showing the cyst that is removed intact.

Case 2: A16-year-old girl with 6 month history of progressive weakness of the lower extremity and inability to walk properly in the last one month was referred to our hospital. On examination, she had spastic paraparesis with a sensory level of T8 down to the feet. MRI conducted in another center demonstrated a posteriorly located cystic mass containing a fluid that demonstrated the same signal characteristics as CSF. The mass extending from T5 to T8 showed epidural fat capping on the poles in T1-weighted images. These findings were compatible with extradural arachnoid cyst.(Figure 2A). Thoracic spine plain X-ray showed widening of the interpedicular distance from T5 to T8. ( Figure 2B) Laminectomy from T5 to T8 was done and the cyst was removed intact and the connecting dural defect hole was closed. ( Figures 2C and 2D) Diagnosis of arachnoid

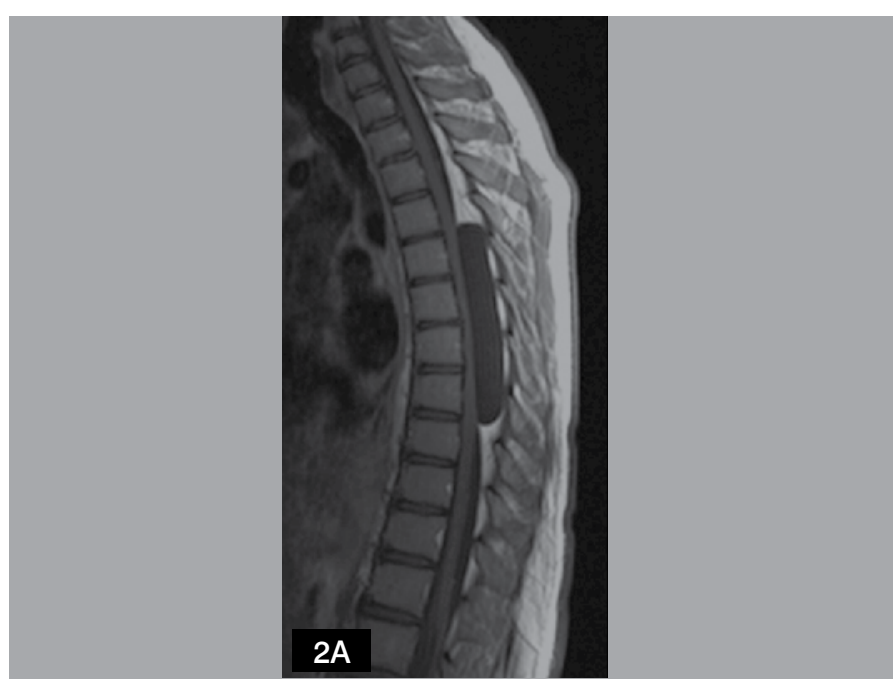

Figue 2A. T1-weighted images of the second case. Showing a hypointense mass at mid thoracic region. Note Fat capping characteristic feature of extradural arachnoid cyst. 
cyst was confirmed in pathologic lab (Figures 2E). With uneventful course, the girl was discharged in the forth postoperative day. She is in good health on the last telephone call a month ago.

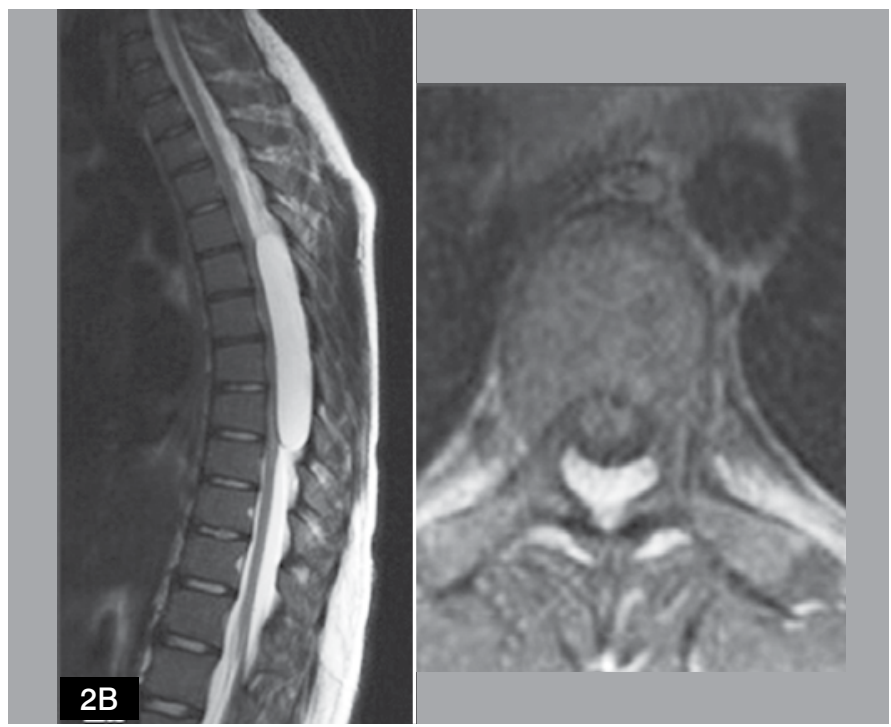

Figure 2B. T2 sagittal and axial T2 weighted image showing a cystic lesion containing CSF. Note flattening of the techal sac at mid thoracic region.

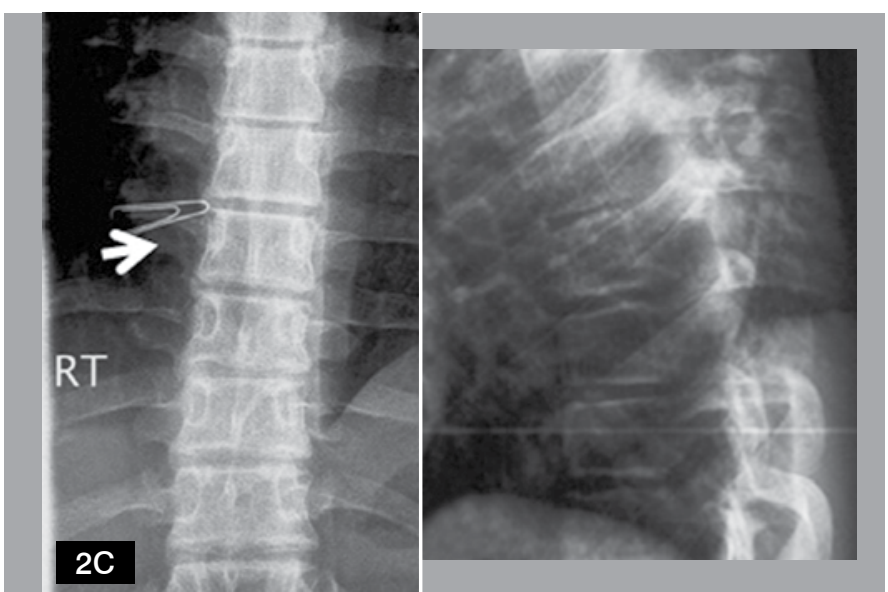

Figure $\mathbf{2 C}$. Plain radiographs, AP view shows thinning of the pedicle, Lateral view shows osseous remodeling and enlarged canal at mid thoracic region.

Case 3: A 62-year-old man was admitted because of attacks of abdominal pain lasting a few seconds for about 30 years. In the last three years, he had experienced feeling of some burning and numbness in his lower extremities. He had noticed difficulty in walking in the last two months.

Thoracic spine MRI conducted in another institute showed a large mass hypointense in T1 and hyperintense in T2 compatible with CSF containing cyst from seventh thoracic vertebrae to ninth (Figure 3A). Presence of fat capping pointed to extradural location of this cyst. The cyst was not enhanced with injection of gadolinium-DTPA.

Plain radiographs performed later disclosed increased interpedicular distance, erosion and thinning of the pedicles in the corresponding levels.(Figure 3B) Reconstructed CT images disclosed the same changes but more clearly.(Figure 3C) In addition, the corresponding intervertebral foramina on the right side were enlarged and united making one large foramen.(Figure 3D )

With diagnosis of extradural arachnoid cyst appropriate thoracic laminectomy was done and a large transparent cyst was exposed, this was removed en-block and the corresponding dural defect was closed. (Figure 3E)

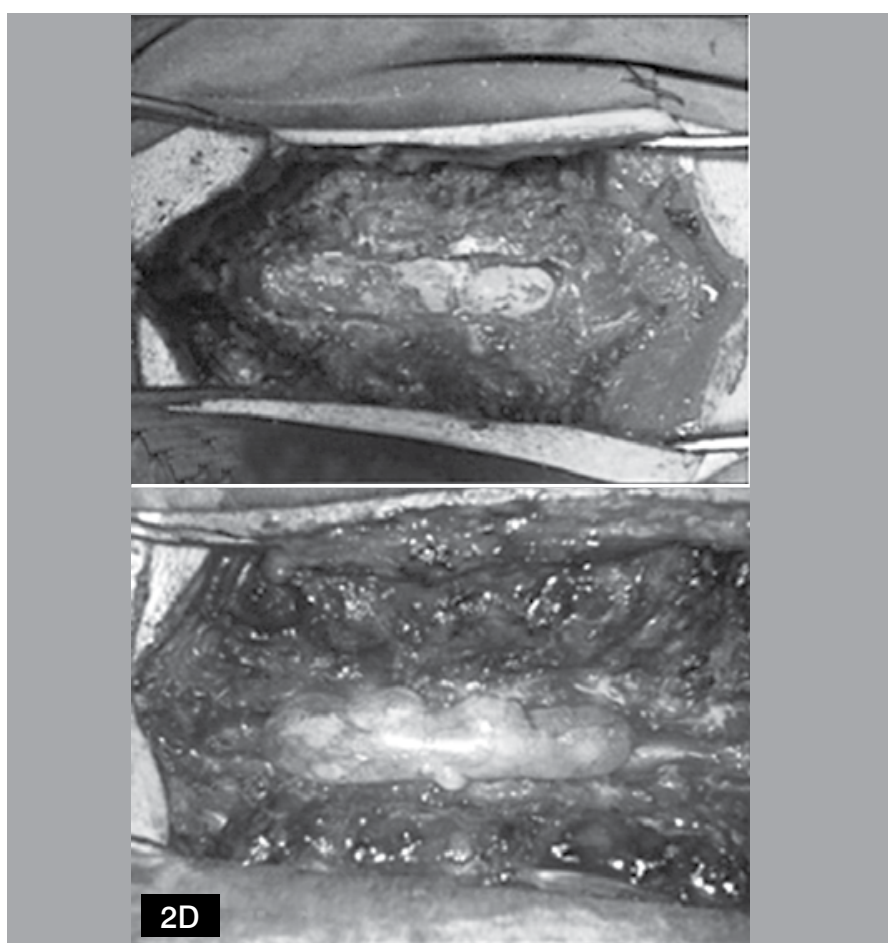

Figure 2D. Demonstrate the cyst in the spinal canal after laminectomy.

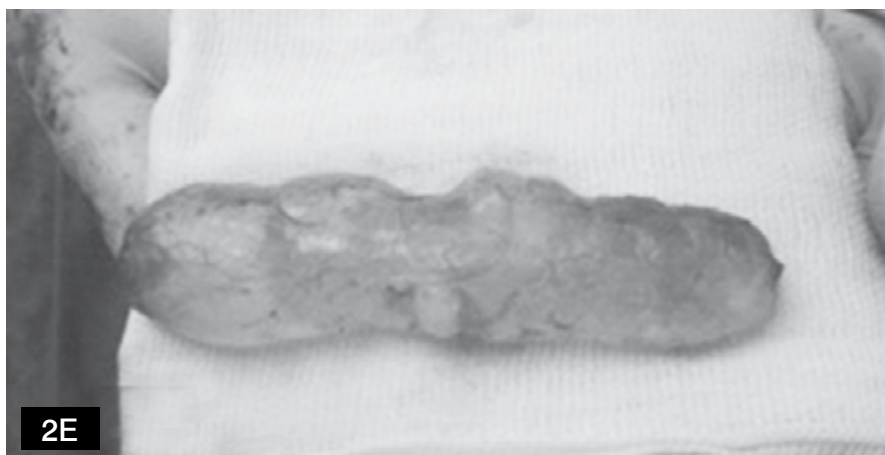

Figure 2E. The cyst removed intact.

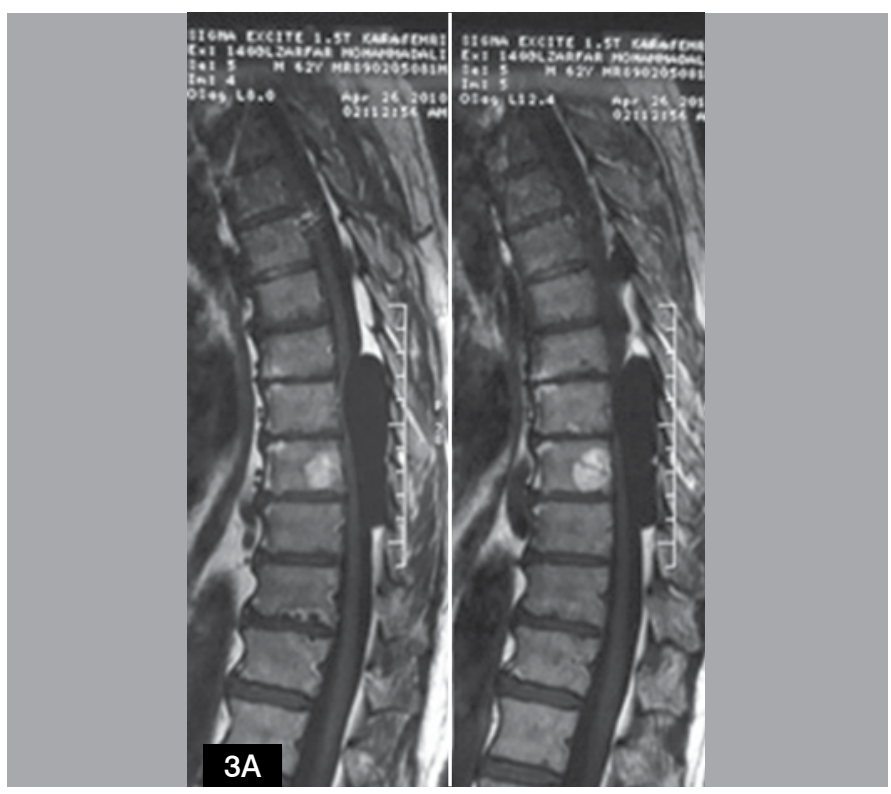

Figue 3A. T1 weighted image, showing a hypointense bi-lobulated mass. 


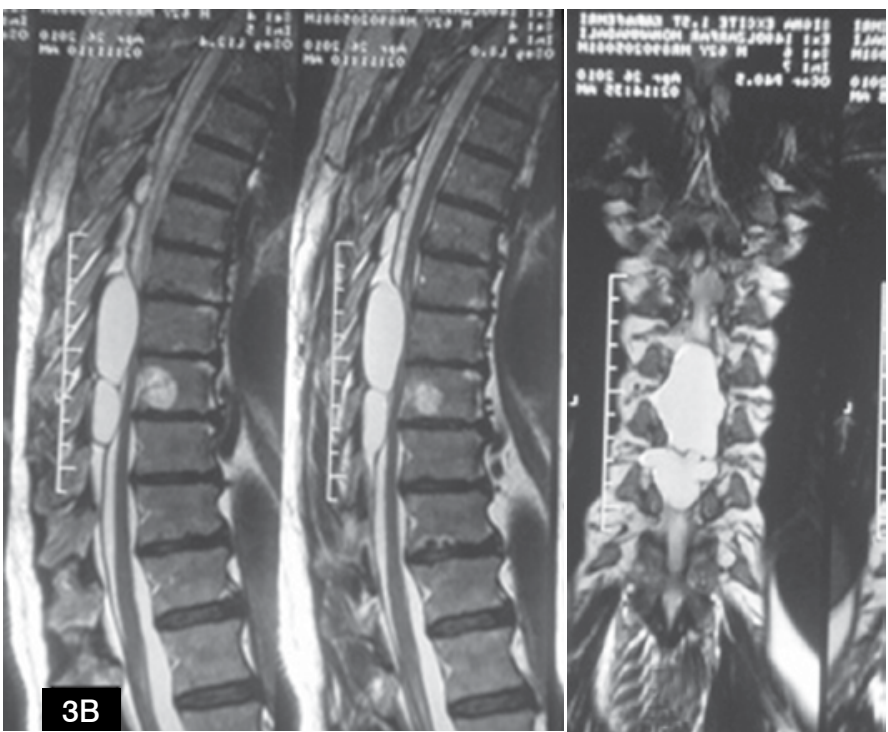

Figure 3B. Demonstrating hyperintense bi-lobulated cystic mass located posterior to the cord with signal intensity similar to CSF, in sagittal and Coronal T2-weighted view.

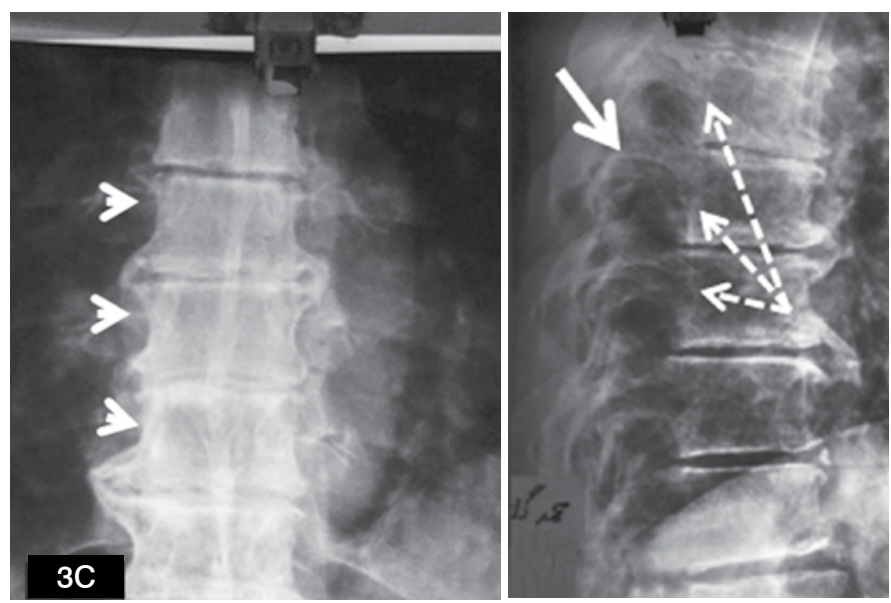

Figure $\mathbf{3 C}$. Depicting thinning of the pedicles and enlarged canal in AP and lateral plain radiographs respectively.

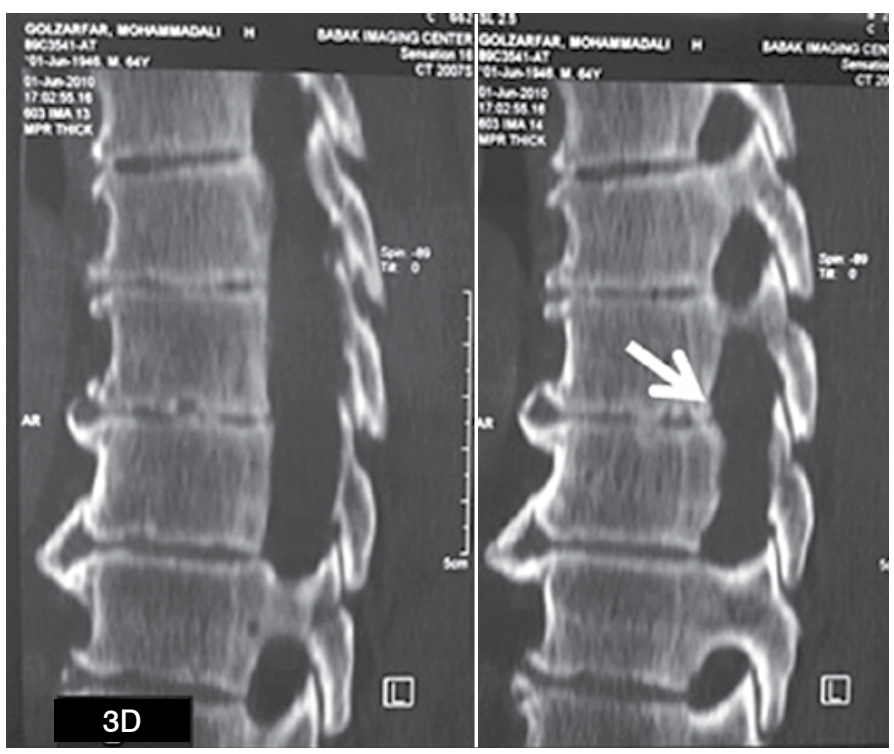

Figure 3D. Reconstructed CT scan of thoracic spine. This shows enlarged canal, two foramina are enlarged an united.

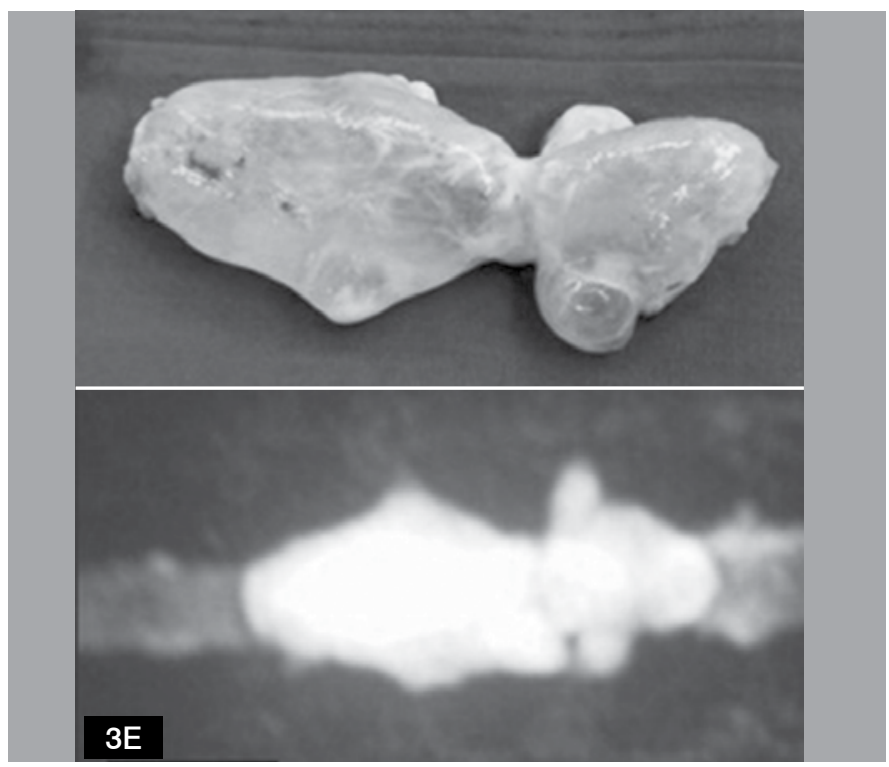

Figure $\mathbf{3 E}$. The cyst removed intact, The shape is quite similar to the image in MRI myelogram.

Case 4: A 55 year-old woman was admitted with difficulty in walking for a year in the last six months. Neurological examination revealed spastic paraparesis with bilateral extensor planter response. Sagittal MR images disclosed an extradural cystic mass locating posterior to the cord and extending from tenth thoracic to twelfth thoracic vertebra.(Figure 4A). Axial MR images showed that the cystic mass has entered and widened a vertebral foramen.(Figure 4B). With diagnosis of extradural arachnoid cyst, laminectomy at the appropriate levels was done and the cyst was removed en-block.(Figure 4C) The defect was sutured later. The patient made excellent recovery where pathology was compatible with extradural arachnoid cyst.
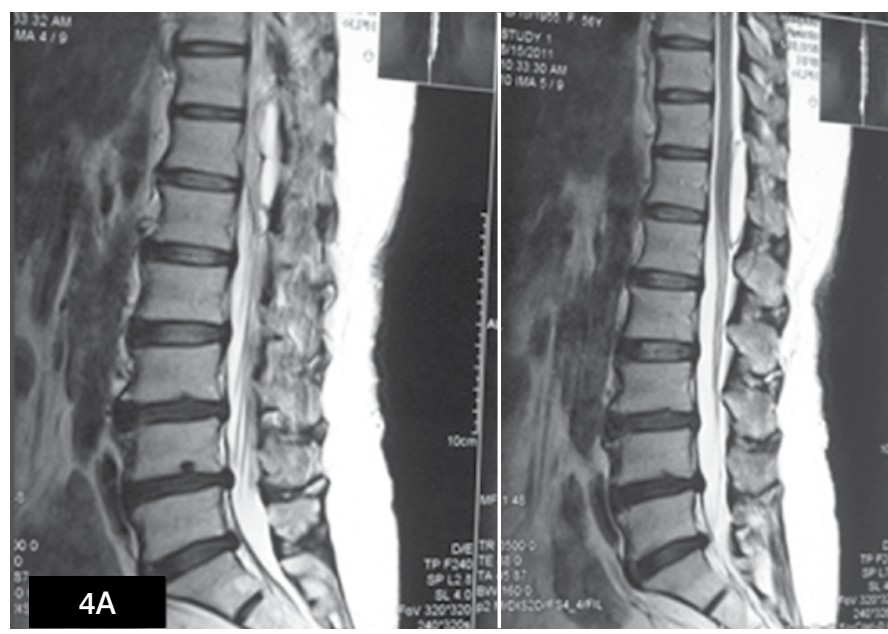

Figure 4A. T2-weighted sagittal MR image showing a cystic mass posterior to the cord and locating in lower thoracic region.

\section{DISCUSSION}

Extradural spinal arachnoid cysts are rare expanding lesions mostly located in the posterolateral aspect of the thoracic or thoracolumbar region displacing the spinal cord or cauda equina anteriorly. 1,3-18,24,29-31

Although, spinal extradural arachnoid cysts might rarely develop after blunt or penetrating traumas, but non-traumatic cysts are generally believed to be congenital. ${ }^{9,12}$ Presence of extradural arachnoid cysts in two and three siblings in a few separate reports 


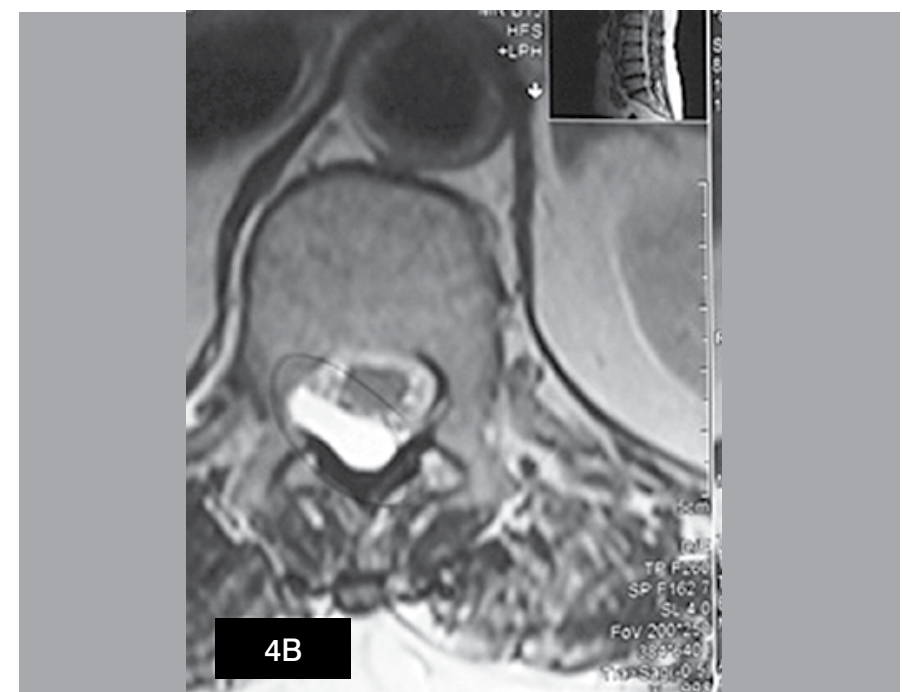

Figure 4B. T2-weighted axial MR image demonstrates that the cyst has a foraminal component.

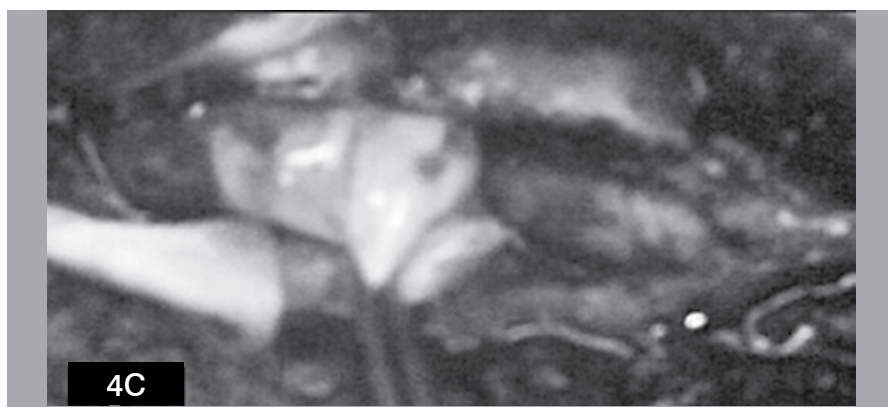

Figure 4C. Intra-operative view depicts that the extradural cyst is easily detached from the dura.

is indicative of the congenital nature of these cysts. ${ }^{23,31-33}$ This is also supported in their association with congenital neural tube defects such as spina bifida occulta and diastematomyelia. ${ }^{34,35}$

Moreover, the presence of these cysts as a part of a hereditary syndrome caused by an autosomal dominant disorder with variable expression including distichiasis or double eyelashes, lymphedema, congenital heart disease and cleft palate point to its genetic etiology. Mutation in FOXC2 has been identified as a cause of this disorder. ${ }^{23,33}$

It is postulated that spinal extradural cysts initially arise from a congenital dural defect. ${ }^{35}$ Such a defect is believed to be the result of the widening of septum posticum. ${ }^{10}$ Out-pouching of the arachnoid from this congenital defect which has constant communication with the intrathecal subarachnoid space result in their enlargement and its shaping into a large extradural cyst. The gradual enlargement of extradural arachnoid cysts is supposed to be through one-way valve effect. ${ }^{36-38}$ However different mechanisms other than this mechanism had been proposed for cyst enlargement and subsequent cord compression. Gradual absorption of the water by hyperosmolar cyst fluid and secretion of CSF by the arachnoid lining of the cyst's wall are other less accepted hypothesis.

From the clinical point of view, the number of the incidentally detected EDA cyst in asymptomatic subjects is more seen with increased use of MRI. ${ }^{26-29} 39,40$ In symptomatic patients, the clinical picture is generally related to the gradual compression of the spinal cord or cauda equina and the corresponding nerve root affection. ${ }^{2-4,6-8,12,13,17-19,24}$ Duration of the symptoms might vary from one month to a quarter of century. $3,9,13,14,17,18,41$ In children, the period prior the correct diagnosis and from diagnosis to surgery is short and is mostly from six to twelve months. ${ }^{4,9,14}$ In adults pre-diagnosis period is usually longer and even the patient might complain of pain about a decade or two before the establishment of correct diagnosis. ${ }^{3,17,18,41}$

The most common presenting symptom is axial or radicular pain. The spectrum of radicular pain varies from intercostal and abdominal pain to upper or lower limb radiculopathy. 2,19,42 Pain usually increase with time but it can be intermittent in nature. Pain is usually followed with parenthesis of the corresponding limbs and later is ensued with

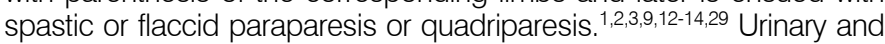
fecal dysfunction are not uncommon. Motor weakness is usually asymmetrical and more prominent than definite sensory loss. ${ }^{8,37}$ The motor weakness is mostly progressive and tend to increase with time, although sudden paraplegia mimicking transverse myelitis has been reported. ${ }^{43}$

Another interesting cause of acute paraplegia or Brown-Sequard syndrome is herniation of the spinal cord through the dural defect into the silent extradural arachnoid cyst. ${ }^{42,44,45}$

In a sub-group of a patients, symptoms are fluctuating with remission and exacerbation. 5,12,18,25,40,46 The symptoms of such patients are exacerbated by Valsalva maneuver in straining and coughing or by gravitational forces. $4,5,8,9,15,18,25$ The fluctuation of the symptoms during straining and exertion is more in the favor of valve like mechanism with transient expansion of the cyst and spinal cord compression. ${ }^{5,9,12,22}$ Valsalva maneuver-induced periapism is a curious example of this event reported by Chen et al. ${ }^{47}$

Mild Kyphoscoliosis is seen frequently during radiological survey of these patients with long standing history, but in most instances it is not of such magnitude that can bring them for medical advice.

The changes of Scheuermann's disease have been described in the vertebral bodies, possibly in relation to a disturbance of the blood supply. High incidence of juvenile dorsal kyphosis and extradural arachnoid cysts in adolescents has been discussed by Cloward and Bucy. ${ }^{46}$

From the radiological point of view, the large and longstanding nature of these cyst result in the widening of spinal canal which is depicted with erosion and thinning of the pedicles, increased interpedicular distances and scalloping of the posterior vertebral body wall in plain radiographs. 2,3,6,8,9,13,22,29,36 Mild to moderate kyphoscoliosis might be seen in longstanding lesions and particularly in multiple cysts. ${ }^{9,26,42,48}$

In the past, water soluble myelography with the ability to demonstrate the compression of the cord by an extradural mass was the only available method. The cyst could be filled with dye through the communicating dural defect, but only if it was obtained delayed with the patient in supine position. ${ }^{29,37}$ However, cystography by direct cyst puncture and injection of the contrast into the cyst was an attractive alternative which has been employed in a few instances in the past. ${ }^{29}$

The expansible effect of the cyst which is demonstrated as scalloping, increased interpedicular distance and enlarged foramina are better visualized in reconstructed CT scans than in plain radiographs. C.T. myelography once was proposed as the diagnostic study of choice for the demonstration of the communication between the cyst and spinal subarachnoid cyst. ${ }^{16}$ However, such a communication can be only visualized in delayed images. ${ }^{29,48}$ CT-guided metrizamide cystography is postulated to determine the possibility of communication between the cysts in the subjects with multiple cysts. ${ }^{14,22}$

$\mathrm{MRI}$ which has great sensitivity and specificity for CSF containing lesions is the diagnostic procedure of choice for extradural spinal arachnoid cysts. In MRI a large cystic lesion with a well-demarcated and lobulated shape located in the posterolateral aspect of the techa is seen and the signal within the cyst is similar to CSF in all sequences. ${ }^{25-27,29,39}$ The exact size of the cyst and multiplicity of the lesion can be easily understood by application of MRI. , Extradural fat is usually absent at the site of the major mass effect and its capping at the superior and inferior poles can be noticed usually in T1-weighted MR images. ${ }^{29}$ Varying degree of the cord atrophy or myelomalacia might be detected by MRI in longstanding cases. 2,4,49 This might reflect the value of this diagnostic tool in predicting the ultimate outcome. Detection of the defect might be feasible in MRI myelogram as was described by Myamato et al. ${ }^{28}$ Kinematic MRI 
which was used for demonstration of the effect of straining on fluctuation of the symptoms, later was used for detection of the defect by demonstrating a pulsating flow void. ${ }^{25,40}$ Therefore it is a valuable method in very large or in multiple cysts in which more than one dural defect is presumed. ${ }^{16}$

The radiological differential diagnosis is wide. Congenital intradural arachnoid cyst which lie posterior to the cord can also erode the bone and expand the canal, but epidural fat capping is absent in these cysts. Dermoid and epidermoid cysts as well as cystic neoplasms usually depict themselves with heterogeneous appearance in $\mathrm{MRI}$ and have a rim which is enhanced with gadolinium. Parasitic cysts should be considered is differential diagnosis in endemic regions. However, cysticercosis is almost always demonstrated as single or multiple small cysts at the time of diagnosis. In extradural hydatid cysts destruction of the adjacent vertebra is usually a striking feature.

Treatment varies and depend on whether the patient is symptomatic or not. With increased application of MRI, more asymptomatic cysts might be detected incidentally. In such instances, there is a controversy between long and careful follow up and immediate surgery. ${ }^{17}$ However, mostly believe that the clinical course of asymptomatic individuals with small cysts can be closely monitored. ${ }^{1,2,7,8,13,14,17,18}$

Conservative management of the patients with mild symptoms is questionable. Majority recommend observing the symptoms of the affected young children in growing ages and postponing surgery until the signs of compression appear. With application of this strategy the surgeon can avoid post surgical deformities. ${ }^{8,13,14,50}$ However, one should be aware of spontaneous herniation of the cord into the extradural arachnoid cyst. In such instance although rare, herniation of the cord in an already asymptomatic patient will result in the rapid development of paraparesis and even paraplegia. ${ }^{44,45}$ Nonetheless, the treatment of choice for symptomatic extradural arachnoid cyst regardless of the age, is excision of the cyst and the closure of the defect. $4,5,8,13,14,17,18,30$ Notably, suturing of the defect is a key point and if not so, the cyst will refill and the symptoms will reappear. ${ }^{33}$ Another option is selective obliteration of the defect without cyst excision, this usually result in cyst's wall shrinkage with a few months to a year. ${ }^{22}$

Nonetheless, the cyst or the dural defect can be accessed through wide laminectomy in adults. 5,9,14,17 However, laminoplasty is preferred in children and in multiple cysts in order to prevent postoperative kyphosis. ${ }^{16,21,22,30}$

In fact, laminoplasty is the recommended treatment of choice for skeletally immature patients with intraspinal mass lesions of the thoracic spine. However, this does not mean that laminoplasty has the ability to prevent postoperative kyphosis in all of the subjects. Development of kyphosis might be seen after laminoplasty but is mostly encountered if it is done in more than five level. ${ }^{51}$ That is the reason why that post-operative kyphosis is more common in multiple cysts which eventually require longer exposure. . $^{10,15,16,51}$

For prevention of postoperative kyphosis in growing children, wearing an appropriate long brace is advocated. ${ }^{15}$ If the deformity control is not provided by an appropriate brace, surgical management of kyphosis similar to Scheuermann's kyphosis with the application of pedicle screw-rod construct plus an appropriate osteotomy is advised..$^{51}$

Despite the fact that association of Scheuermann's kyphosis and extradural arachnoid cyst since Cloward and Bucy has not been reported so far, however in such instance, appropriate surgery for kyphosis and the cyst should be done simultaneously in one session
In very large cysts extending several levels to avoid long laminoplasty, two different methods are recommended. In the first method, with small laminectomy and limited cyst wall fenestration, the surgeon can reach the defects with the aid of endoscope and close it with a special clip. By the second method, one can communicate the cyst widely to subarachnoid space through a limited laminectomy, this procedure is so-called cystothecostomy. ${ }^{52}$

Moreover, In multiple extradural arachnoid cyst in whom the presence of more than one dural defect is suspected and is confirmed preoperatively, an appropriate number of skip laminectomy or fenestration can be done in order to access and close the defects. However, prerequisite of this method is defining the exact location of the dural defects preoperatively with application of kinematic MRI or their intraoperative visualization with the aid of an endoscope Nonetheless, the efficacy and long-term results of these surgical techniques have remained open for discussion.

Percutaneous cyst aspiration either CT or MRI guided is worthless and despite the initial recovery and temporary relief, the symptoms undoubtedly recur with reaccumulation of the cyst. ${ }^{53}$

Cystoperitoneal shunt as a primary mode of treatment will fail, because the cyst content is constantly refilled. ${ }^{33}$

In the case of recurrence, cystoperitoneal shunt has been advised with success. ${ }^{54}$

The outcome of the surgically treated patients with extradural spinal arachnoid cysts depends highly on the patient's age, duration of the symptoms and degree of neurological impairment. The prognosis will be very good if surgery is performed before the spinal cord or quad equina become irreversibly compressed. ${ }^{49}$

Surgical outcome is influenced adversely by duration of the symptoms and to some extent also by increasing age of the patients. If the condition is diagnosed before the appearance of serious neural impairment chance of excellent recovery is high. ${ }^{14,17,19,41}$ However, with occurrence of myelomalacia or cord atrophy the prognosis is less satisfactory. ${ }^{49}$ In the subjects with a longstanding history of neurological dysfunction, acceptable recovery is exceptional. ${ }^{15}$

\section{CONCLUSION}

With increased use of MRI, more extradural arachnoid cyst will be undoubtedly detected in the upcoming years; therefore all spine surgeons should be familiar with the proper management of these cysts.

Although, diverse therapeutic approaches have been so far described, it should be noted that the aim of surgical intervention is not only decompression but is also prevention of cyst refilling and avoiding the recurrence which can be achieved by finding the defect and its obliteration. Further attention should be paid to the young children in growing age particularly in those with multilevel cysts where post-operative kyphosis is more probable. Such a deformity, beside cosmesis can result in pain and untoward cardio- respiratory problems

For prevention, although en-block laminatomy and subsequent laminoplasty may maintain the spinal stability and decrease the risk of postoperative kyphosis, careful and periodic follow-up is required. Post-operative orthosis for about 12 weeks and periodic clinical and radiological assessment is strongly advised in this age group. In the case of progressive kyphosis, instrumentation should be achieved.

All the authors declare that there is no potential conflict of interest referring to this article.

\section{REFERENCES}

1. Chae KH, Kim SW, Shin H. Septated extradural arachnoid cyst in thoracolumbar spine causing myelopathy. J Korean Neurosurg Soc. 2006:40:381-3.

2. Chang IC, Chou MC, BellWR, Lin ZI. Spinal cord compression caused by extradural arachnoid cysts. Clinical examples and review. Pediatr Neurosurg. 2004;40(2):70-4

3. Choi JY, Kim SH, Lee WS, Sung KH. Spinal extradural arachnoid cyst. Acta Neurochir (Wien). 2006;148(5):579-85

4. de Oliveira RS, Amato MC, Santos MV, Simão GN, Machado HR. Extradural arachnoid cysts in children. Childs Nerv Syst. 2007;23(11):1233-8.

5. Ersahin $Y$, Yildizhan A, Seber N. Spinal extradural arachnoid cyst. Childs Nerv Syst. 1993;9(4):250-2.

6. Kumar K, Malik S, Schulte PA. Symptomatic spinal arachnoid cysts: report of two cases with review of the literature. Spine (Phila Pa 1976). 2003;28(2):E25-9.

7. Liu $H$, Ishihara $H$, Kawaguchi $Y$, Abe $Y$, Otaya $A$, Sakurai $S$, et al. Large thoracolumbar extradural arachnoid cyst. Orthopedics. 2004;27(2):225-6.

8. Liu JK, Cole CD, Kan P, Schmidt MH. Spinal extradural arachnoid cysts: clinical, radiological, and surgical features. Neurosurg Focus. 2007;22(2):E6. 
9. McCrum C, Williams B. Spinal extradural arachnoid pouches. Report of two cases. J Neurosurg. 1982;57(6):849-52.

10. Perret G, Green D, Keller J. Diagnosis and treatment of intradural arachnoid cysts of the thoracic spine. Radiology. 1962;79:425-9.

11. Prevo RL, Hageman G, Bruyn RP, Broere G, van de Stadt J. Extended extradural spinal arachnoid cyst: an unusual cause of progressive spastic paraparesis. Clin Neurol Neurosurg. 1999;101(4):260-3.

12. Roski RA, Rekate HL, KurczynskiTW, Kaufman B. Extradural meningeal cyst. Case report and review of the literature. Childs Brain. 1984:11(4):270-9.

13. Sato K, Nagata K, Sugita Y. Spinal extradural meningeal cyst: correct radiological and histopathological diagnosis. Neurosurg Focus. 2002;13(4):ecp1.

14. Stechison MT, Hendrick EB, Cohen E. Spinal extradural arachnoid cyst. Pediatr Neurosci. 1989;15(1):36-8.

15. Suryaningtyas W, Arifin M. Multiple spinal extradural arachnoid cysts occurring in a child. Case report. J Neurosurg. 2007;106(Suppl 2):158-61.

16. Takagaki T, Nomura T, Toh E, Watanabe M, Mochida J. Multiple extradural arachnoid cysts at the spinal cord and cauda equina levels in the young. Spinal Cord. 2006;44(1):59-62

17. Tureyen K, Senol N, Sahin B, Karahan N. Spinal extradural arachnoid cyst. Spine J. 2009;9(8):e10-5

18. Uemura K, Yoshizawa T, Matsumura A, Asakawa H, Nakamagoe K, Nose T. Spinal extradural meningeal cyst. Case report. J Neurosurg. 1996;85(2):354-6.

19. Vaccaro M, Moschiano F. A woman with abdominal pain and headache. Neurol Sci. 2009:30(Suppl 1):S141-3.

20. Hamamcioglu MK, Kilincer C, Hicdonmez T, Simsek O, Birgili B, Cobanoglu S. Giant cervicothoracic extradural arachnoid cyst: case report. Eur Spine J. 2006;15(Suppl 5):595-8.

21. Kahraman S, Anik I, Gocmen S, Sirin S. Extradural giant multiloculated arachnoid cyst causing spinal cord compression in a child. J Spinal Cord Med. 2008;31(3):306-8.

22. Myles LM, Gupta N, Armstrong D, Rutka JT. Multiple extradural arachnoid cysts as a cause of spinal cord compression in a child. Case report. J Neurosurg. 1999:91(Suppl1):116-20.

23. Yabuki S, Kikuchi S. Multiple extradural arachnoid cysts: report of two operated cousin cases. Spine (Phila Pa 1976). 2007;32(20):E585-8.

24. Rashid M, Syed A, Ahmad I, Ekramullah. Giant thoracolumbar extradural arachnoid cyst: a case report. Acta Orthop Belg. 2008;74(5):709-13.

25. Doita M, Nishida K, Miura J, Takada T, Kurosaka M, Fujii M. Kinematic magnetic resonance imaging of a thoracic spinal extradural arachnoid cyst: an alternative suggestion for exacerbation of symptoms during straining. Spine (Phila Pa 1976). 2003;28(12):E229-33.

26. Gray L, Djang WT, Friedman AH. MR imaging of thoracic extradural arachnoid cysts. J Comput Assist Tomogr. 1988;12(4):646-8.

27. Jena A, Gupta RK, Sharma A, Prakesh VE, Khushu S. magnetic resonance diagnosis of spinal arachnoid cyst. A report of two cases. Childs Nerv Syst. 1990;6(2):107-9.

28. Miyamoto M, Kim K, Matsumoto R, Isobe M, IsuT. Utility of preoperative magnetic resonance imaging myelography for identifying dural defects in patients with spinal extradural arachnoid cysts: case report. Neurosurgery. 2006;59(4):E941.

29. Rimmelin A, Clouet PL, Salatino S, Kehrli P, Maitrot D, Stephan M, et al. Imaging of thoracic and lumbar spinal extradural arachnoid cysts: report of two cases. Neuroradiology. 1997;39(3):203-6.

30. Furtado SV, Thakar S, Murthy GK, Dadlani R, Hegde AS. Management of complex giant spinal arachnoid cysts presenting with myelopathy. J Neurosurg Spine. 2011;15(1):107-12.

31. Bergland RM. Congenital intraspinal extradural cyst. Report of three cases in one family. J Neurosurg. 1968;28(5):495-9.

32. Chynn KY. Congenital spinal extradural cyst in two siblings. Am J Roentgenol Radium Ther Nucl Med. 1967:101(1):204-15.

33. Kanaan IN, Sakati N, Otaibi F. Type I congenital multiple intraspinal extradural cysts as- sociated with distichiasis and lymphedema syndrome. Surg Neurol. 2006;65(2):162-6.

34. Apel K, Sgouros S. Extradural spinal arachnoid cysts associated with spina bifida occulta. Acta Neurochir (Wien). 2006:148(2):221.

35. Rabb CH, McComb JG, Raffel C, Kennedy JG. Spinal arachnoid cysts in the pediatric age group: an association with neural tube defects. J Neurosurg. 1992:77(3):369-72.

36. Lake PA, Minckler J, Scanlan RL. Spinal epidural cyst: theories of pathogenesis. Case report. J Neurosurg. 1974;40(6):774-8.

37. Nabors MW, Pait TG, Byrd EB, Karim NO, Davis DO, Kobrine Al, et al. Updated assessment and current classification of spinal meningeal cysts. J Neurosurg. 1988;68(3):366-77.

38. Rohrer DC, Burchiel KJ, Gruber DP. Intraspinal extradural meningeal cyst demonstrating ball-valve mechanism of formation. Case report. J Neurosurg. 1993;78(1):122-5.

39. Kim KS, Weinberg PE. Magnetic resonance imaging of a spinal extradural arachnoid cyst. Surg Neurol. 1986;26(3):249-52

40. Neo M, Koyama T, Sakamoto T, Fujibayashi S, Nakamura T. Detection of a dural defect by cinematic magnetic resonance imaging and its selective closure as a treatment for a spinal extradural arachnoid cyst. Spine (Phila Pa 1976). 2004;29(19):E426-30.

41. Winer JB, Harding AE, Symon L, Kingsley DP. Lumbar extradural arachnoid cyst pre senting as a conus lesion in a man aged 77 years. J Neurol Neurosurg Psychiatry. 1989;52(1):126

42. Marbacher S, Barth A, Arnold M, Seiler RW. Multiple spinal extradural meningeal cysts presenting as acute paraplegia. Case report and review of the literature. J Neurosurg Spine. 2007:6(5):465-72.

43. Dickson RA, Arabi K, Goodfellow J. Congenital spinal extradural cyst (lateral meningocele) simulating acute transverse myelitis. Report of a case. J Bone Joint Surg Br. 1978;60-B(3):412-5

44. Masuzawa H, Nakayama $H$, Shitara N, Suzuki T. Spinal cord herniation into a congenital extradural arachnoid cyst causing Brown-Séquard syndrome. Case report. J Neurosurg 1981:55(6):983-6

45. Nejat F, Cigarchi SZ, Kazmi SS. Posterior spinal cord herniation into an extradural thoracic arachnoid cyst: surgical treatment. Case report and review of the literature. J Neurosurg 2006;104(Suppl 3):210-1.

46. Cloward RB, Bucy PC. Spinal extradural cyst and kyphosis dorsalis juvenilis. Am J Roentgenol. 1937:38:681-706.

47. Chen WL, Tsai WC, Tsao YT. Valsalva maneuver-induced priapism: a hidden culprit. J Sex Med. 2009;6(4):1181-4

48. DiSclafani A 2nd, Canale DJ. Communicating spinal arachnoid cysts: diagnosis by delayed metrizamide computed tomography. Surg Neurol. 1985;23(4):428-30.

49. Ergun T, Lakadamyali $\mathrm{H}$. Multiple extradural spinal arachnoid cysts causing diffuse myelomalacia of the spinal cord. Neurologist. 2009;15(6):347-50.

50. Ergun E, Börcek AO, Cemil B, Doğulu F, Baykaner MK. Should we operate all extradural spinal arachnoid cysts? Report of a case. Turk Neurosurg. 2008;18(1):52-5.

51. Amhaz HH, Fox BD, Johnson KK, WhiteheadWE, Curry DJ, Luerssen TG, et al. Postlaminoplasty kyphotic deformity in the thoracic spine: case report and review of the literature. Pediatr Neurosurg. 2009:45(2):151-4

52. Dev R, Singh G, Singh SK, Mamgain A. Cystothecostomy: a new technique to treat long segment spinal extradural arachnoid cyst. Br J Neurosurg. 2008;22(4):585-7.

53. Bellavia R, King JT Jr, Naheedy MH, Lewin JS. Percutaneous aspiration of an intradural/ extradural thoracic arachnoid cyst: use of MR imaging guidance. J Vasc Interv Radiol. 2000;11(3):369-72

54. Jensen $F$, Knudsen $V$, Troelsen $S$. Recurrent intraspinal arachnoid cyst treated with a shunt procedure. Acta Neurochir (Wien). 1977;39(1-2):127-9. 